ORCID: 0000-0001-6631-4246, канд. пед. наук Марийский государственный университет, г. Йошкар-Ола, Россия

\title{
ВОЗДЕЙСТВИЕ СОСТОЯНИЯ ГИПОДИНАМИИ И ТРЕНИРОВОЧНЫХ НАГРУЗОК НА МЕТАБОЛИЗМ ОРГАНИЗМА СТУДЕНТОК УНИВЕРСИТЕТА
}

Аннотация. Исследовано влияние уровня двигательной активности у двух групп студенток университета: первая группа - уровень бытовой и учебной физической активности характерно состоянию гиподинамии, вторая - систематически занимающихся тренировками повышения спортивного мастерства. Установлено, что двигательная активность, включающая систематические тренировочные нагрузки, положительно влияет на метаболизм организма и является эффективным средством профилактики метаболического синдрома. Низкая физическая активность - причина метаболических изменений, связанных с дистрофией мышечной ткани в результате преобладания катаболизма в белковом обмене и нарушением липидного обмена с преобладанием анаболизма липидов.

Ключевые слова: двигательная активность, метаболизм, биоимпедансный анализ, компонентный состав массы тела.

Nikolaev V.T.

ORCID: 0000-0001-6631-4246, Ph.D.

Mari State University,

Yoshkar-Ola, Russia

\section{THE EFFECTS OF HYPODYNAMY \\ AND TRAINING LOADS ON METABOLISM OF FEMALE STUDENTS}

Annotation. The article is devoted to the study of the influence of the level of motor activity of two groups of university students: the first group of students with the level of everyday and educational physical activity that is a hypodynamy-related condition, the second group of people who are systematically engaged in sports mastery improvement trainings. It has been established that physical activity, including systematic training loads, has a positive effect on the body's metabolism and is an effective means of prevention of metabolic syndrome. Low physical activity is the cause of metabolic changes associated with muscle tissue dystrophy as a result of the predominance of catabolism in protein metabolism and lipid metabolism disorders with a predominance of lipid anabolism.

Keywords: physical activity, metabolism, bioimpedance analysis, body mass composition.

В студенческой среде в образовательном процессе в вузах выделяются большинство студентов с низким уровнем двигательной активности, у которых двигательная активность связана только с действиями в быту и с учебным процессом, и с более высоким уровнем двигательной активности - систематически занимающихся фитнес тренировками и повышением спортивного мастерства, их в меньшем количестве. Поэтому актуально проводить диагностику состояния их метаболизма и на основе результатов исследования 
предоставлять индивидуальные рекомендации по направленности и интенсивности физических нагрузок и рационального питания, что способствует профилактике метаболического синдрома и приобщению здоровому образу жизни.

Цель исследования. Выявить особенности в метаболизме организма студенток университета в зависимости от уровня двигательной активности: первая группа -уровень бытовой и учебной физической активности, включая и учебные занятия по физической культуре, вторая - систематически занимающихся тренировками в фитнесе и повышением спортивного мастерства.

Для определения состояния метаболизма исследуемых девушек использовали биоимпедансный анализатор АВС-01 «Медасс» с применением программ персонального компьютера. Всего в исследовании приняли участие 60 студенток Марийского государственного университета, из них, 30 - посещали только учебные занятия по дисциплине «физическая культура», они включены в исследования методом случайной выборки учебной группы института естественных наук и фармации (ИЕНиФ) и были отнесены основной медицинской группе, остальные 30 девушек - целенаправленно занимались в группах спортивного совершенствования циклическими видами спорта (легкая атлетика, лыжные гонки), многоборьем (летний полиатлон), игровыми видами спорта (волейбол, баскетбол), также были включены в исследования методом случайной выборки. Статистическая обработка полученных результатов исследования проведена в стандартном пакете «STATISTICA 6.1» с использованием дисперсионного анализа.

Условия жизни студентов, особенно образовательная деятельность, такова, что у них время, проводимое физически активно снижается особенно в старших курсах обучения, а время нахождения в положении сидя, инактивности, в учебных аудиториях, библиотеке вуза и дома за компьютером, мобильным телефоном, телевизором увеличивается. Это характеризуется, как состояние гиподинамии, следствием которого является нарушение метаболизма организма. Метаболизм, или обмен веществ, представляет все непрерывные химические реакции в каждой клетке организма человека, которые превращают поступившие пищевые вещества в энергию для жизнедеятельности и используют как «строительный материал». Большая часть энергии, производимая метаболизмом, используется всеми тканями организма, различающиеся величиной потребности в энергии, для поддержания их функционирования в состоянии покоя в течение суток называется основным обменом (метаболизмом), или базовым метаболизмом, или базальным метаболизмом, или базовой скоростью метаболизма, или скоростью метаболизма в покое. Скорость метаболизма в покое на самом деле составляет огромное количество от всех калорий, которые расходуется организмом человека в течение суток.

Биоимпедансный анализ достаточно информативный метод определения показателей основного метаболизма организма человека. Основной обмен (OO) является базовой основой для расчета калорийности приема пищи при занятии спортом и фитнесом. ОО здорового взрослого человека примерно составляет 1 ккал на 1 кг веса за 1 час. Величина ОО зависит от пола, возраста, роста, массы, температуры тела и других факторов. Средние данные ОО у студенток в исследуемых группах, занимающихся повышением спортивного мастерства, и физической культурой в учебном процессе, у которых низкая двигательная активность, соответственно составили: $1339,50 \pm 14,38$ ккал и $1273,10 \pm 14,38$ ккал, различия статистически значимые ( $\mathrm{p}=0,001836)$ (табл. 1). Более высокий показатель ОО у девушек, занимающихся спортом, обосновывается более значительным содержанием скелетно-мышечной массы (CMM) по сравнению с девушками, занимающихся физической культурой в учебном 
процессе. Следует отметить, что основным потребителем энергии в организме человека в условиях покоя и двигательной деятельности является мышечная система [1].

В протоколе обследования положение маркера удельного основного обмена (УОО) указывает на относительную интенсивность обменных процессов. Причиной изменений УОО могут быть гормональные нарушения, воздействия фармакологии, состояния, вызванные объемными и высоко интенсивными тренировочными и др. Дисперсионный анализ показателей УОО показал отсутствие статистически значимых различий $(p=0,094255)$ у девушек, занимающихся спортом и физической культурой в учебном процессе (табл. 1).

Таблица 1

Средние показатели метаболизма в организме девушек, занимающихся спортом и физической культурой в учебном процессе $(\mathrm{M} \pm \mathrm{m})$

\begin{tabular}{|l|c|c|c|c|c|}
\hline \multirow{2}{*}{\multicolumn{1}{c|}{ Показатели }} & Занимающиеся & Занимающиеся & \multicolumn{3}{|c|}{ Различия } \\
\cline { 4 - 6 } & спортом & физкультурой & Абсол & $\%$ & $\mathrm{P}$ \\
\hline $\mathrm{OO}($ ккал)* & $1339,50 \pm 14,38$ & $1273,10 \pm 14,38$ & 66,4 & 4,96 & 0,001836 \\
\hline УОО(калл/м $\left.{ }^{2}\right)$ & $853,86 \pm 8,29$ & $833,90 \pm 8,29$ & 19,96 & 2,33 & 0,094255 \\
\hline
\end{tabular}

Примечание: ОО - основной обмен; УОО - удельный основной обмен; * - различия статически значимые $(\mathrm{P}<0,05)$.

В таблице 2 показаны по средние данные компонентного состава массы тела студенток двух групп, отличающихся уровнем двигательной активности. Рассмотрим долю жировой ткани в массе тела девушек. Повышенное содержание жира (более 27\%) и ожирение (более $32 \%$ ) это серьезная проблема для здоровья организма человека. Персональный анализ протоколов биоимпедансного анализа показывает, что у девушек с нормальной или даже сниженной индексом массы тела содержание жировой ткани определяется выше популяционных норм, при этом у них же показатели активной клеточной массы (AКМ) и скелетно-мышечной массы (CMM) значительно ниже популяционных норм. Это отражает их организм в состоянии гиподинамии. Средние показатели жировой ткани у студенток, занимающихся спортом и физической культурой в учебном процессе, соответственно составили: $13,62 \pm 0,54$ кг и 15,44 $\pm 0,54$ кг, различия статистически значимые $(p=0,007586)$. Следует обратить внимание на то, что у студенток в исследуемых группах средние показатели массы тела и индекса массы тела не имеют статистически значимых различии ( $\mathrm{p}=0,156527$ и $\mathrm{p}=0,463336$, соответственно).

Таблица 2

Средние данные состава массы тела девушек, занимающихся спортом и физической культурой в учебном процессе $(\mathrm{M} \pm \mathrm{m})$

\begin{tabular}{|l|c|c|c|c|c|}
\hline \multirow{2}{*}{\multicolumn{1}{c|}{ Показатели }} & Занимающиеся & Занимающиеся & \multicolumn{3}{|c|}{ Различия } \\
\cline { 5 - 6 } & спортом & физкультурой & Абсол & $\%$ & $\mathrm{P}$ \\
\hline ЖМ(кг)* & $13,62 \pm 0,54$ & $15,44 \pm 0,54$ & $-1,82$ & 13,36 & 0,007586 \\
\hline Акм(кг)* & $22,89 \pm 0,45$ & $20,80 \pm 0,45$ & 2,09 & 9,13 & 0,001850 \\
\hline Доля АКМ(\%)* & $57,05 \pm 0,27$ & $55,21 \pm 031$ & 1,84 & 3,22 & 0,003769 \\
\hline СММ(кг)* & $20,08 \pm 0,38$ & $18,33 \pm 0,38$ & 1,75 & 8,71 & 0,002235 \\
\hline Доля СММ(\%)* & $50,17 \pm 0,21$ & $48,65 \pm 0,29$ & 1,52 & 3,02 & 0,002671 \\
\hline ТМ(кг)* & $40,12 \pm 0,64$ & $37,67 \pm 0,64$ & 2,45 & 6,11 & 0,008991 \\
\hline ОВО(кг) & $29,37 \pm 0,46$ & $27,57 \pm 0,46$ & 1,80 & 6,13 & 0,009070 \\
\hline
\end{tabular}

Примечание: ЖМ - жировая масса; АКМ - активная клеточная масса; СММ - скелетно-мышечная масса; ТМ - тощая масса; ОВО - общая вода организма; * - различия статически значимые $(\mathrm{P}<0,05)$. 
В протоколе диагностики положение маркера на шкале тощей (без жировой) массы указывает на конституциональные особенности индивида. Так, положение маркера в области середины интервала нормальных значений принято рассматривать как мезоморфный (нормостенический) тип телосложения. Средний показатель тощей массы у девушек в исследуемой группе занимающихся спортом установлен 40,12 $\pm 0,64$ кг, а у девушек в

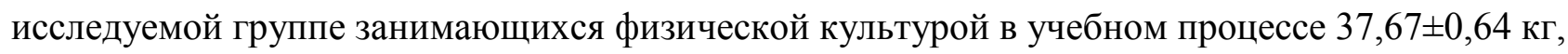
различия статистически значимые ( $\mathrm{p}=0,008991)$. Эти данные свидетельствуют о преобладании белкового метаболизма, что привело к гипертрофии мышечной системы у девушек в исследуемой группе, занимающихся спортом [2].

Количественного содержания метаболически активных тканей в организме человека диагностируется величиной активной клеточной массы (АКМ). Средние показатели АКМ у студенток в исследуемых группах, занимающихся спортом и физической культурой в учебном

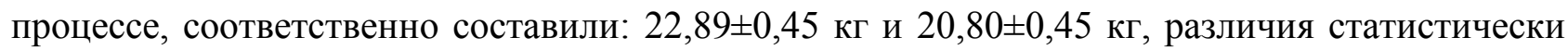
значимые ( $\mathrm{p}=0,001850)$. Более высокое содержание АКМ у девушек, занимающихся спортом указывает на достаточное поступление белка с Процентная доля АКМ (\% АКМ) в тощей массе служит критерием двигательной активности и физической работоспособности спортсменов, а у малоподвижных людей степени выраженности гиподинамии. Установлены статистически

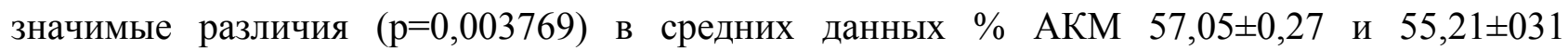
соответственно у студенток в исследуемых группах, занимающихся спортом и физической культурой в учебном процессе. Преобладание \% АКМ у девушек, занимающихся спортом, соответствует высокому уровню двигательной активности, а у девушек, занимающихся физической культурой в учебном процессе более низкие значения \% АКМ можно связать с имеющейся тенденцией к гиподинамии.

Основной составляющей АКМ является скелетно-мышечная масса (CMM). Средний показатель СММ у девушек в исследуемой группе занимающихся спортом составил: $20,08 \pm 0,38$ кг, а у девушек в исследуемой группе занимающихся физической культурой в учебном процессе $-18,33 \pm 0,38$ кг, различия статистически значимые $(\mathrm{p}=0,002235)$. Средние показатели \% СММ у студенток в исследуемых группах, занимающихся спортом и физической культурой в учебном процессе, соответственно составили: $50,17 \pm 0,21 \%$ и $48,65 \pm 0,29 \%$ различия статистически значимые $(\mathrm{p}=0,002671)$. Данные показатели отражают, что в исследуемой группе, занимающихся спортом, преобладает анаболизм в белковом метаболизме, что связано более высокой физической подготовленностью.

Средний показатель ОВО у девушек в исследуемой группе, занимающихся спортом

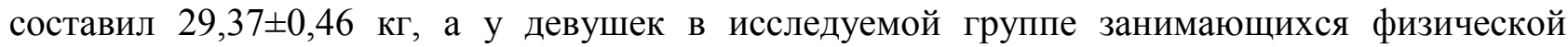

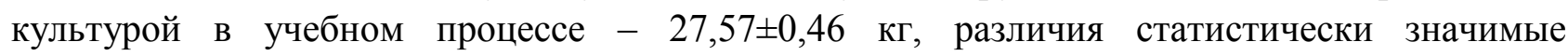
( $\mathrm{p}=0,009070)$. Следует отметить, что девушки, занимающиеся спортом, следят за потреблением воды.

По влиянию двигательной активности на организм человека, как физической нагрузки, необходимо выделить фоновое и тренировочное воздействие. У большинства студентов двигательная активность соответствует фоновому уровню: передвижение в быту, до транспорта, от транспорта до учебного заведения, переходы по учебным аудиториям и прогулки. Данные малоинтенсивные и не продолжительные физические нагрузки не активизируют функционирование органов и систем организма человека, то есть отсутствует тренировочный эффект. Такой образ жизни студенчества способствует метаболическим нарушениям, что приводит повышенному содержанию жировой массы тела и ожирению. И как следствие риск развития различных хронических заболевании. Хотя имеется в учебном процессе вузе учебно-тренировочные занятия по физической культуре, проводимые 1-2 раза 
в неделю в зависимости от курса обучения, не способствуют достижению желаемого тренировочного эффекта. Это характерно для исследуемой группы студенток, ограничивающие свою двигательную активность учебными занятиями по физической культуре. Вероятно одной из причин, нарушения липидного метаболизма во время продолжительного пребывания в позе сидя связано с тем, что состояние гиподинамии с уменьшением количества сокращений скелетных мышц может приводить к снижению активности липопротеинлипазы - фермента, гидролизующего жиры липопротеинов, и к уменьшению клиренса триглицеридов, что приводит, повышению уровня триглицеридов в жировой ткани и к развитию центрального ожирения. Установлено, что сокращение времени, нахождения в положении сидя усиливает активность липопротеинлипазы [3]. Также выявлено отрицательное влияние на углеводный обмен в условиях малоподвижного образа жизни может осуществляться через снижение стимулированной секреции инсулина, развитием инсулинорезистентности вследствие снижения содержания GLUT-4, который является инсулинозависимым белком-переносчиком глюкозы в мышцах [3].

Бесспорно, физическая активность является незаменимым компонентом поддержания метаболизма организма человека в индивидуальных физиологических нормах, что является базовой основой здоровья человека. Положительное воздействие систематически, выполняемых физических упражнений заключается в целом комплексе процессов, отражающихся на обмене веществ, в т. ч. гомеостазе липидов и углеводов, а также в поддержании и увеличении скелетно-мышечной массы. Этому свидетельствуют, результаты исследования студенток, регулярно занимающихся повышением спортивного мастерства.

Физическая активность является основным компонентом поддержания метаболического здоровья. Положительное влияние регулярных тренировочных нагрузок заключается в целом комплексе процессов, отражающихся на метаболизме, в том числе гомеостазе углеводов, частичном катаболизме липидов, что приводит к снижению жировой массы, а также анаболизме белков, что способствует увеличению скелетно-мышечной массы.

\section{Литература}

1. Николаев В.Т. Эффективность периодизации годичного макроцикла тренировок в силовом фитнесе у девушек // Наука и спорт: современные тенденции. Казань: Поволжская ГАФКСиТ. 2020. Т. 8. № 2. С. 32-43.

2. Николаев В.Т. Сезонные изменения метаболизма в организме человека и тренировочный процесс в фитнесе у девушек // Физическое воспитание и студенческий спорт глазами студентов: материалы VI Международной научно-практической конференции. Казань, 13-14 ноября 2020 г. Казань: Изд-во КНИТУ-КАИ, 2020. С. 363-366.

3. Hamilton M.T., Hamilton D.G., Zderic T.W. Role of low energy expenditure and sitting in obesity, metabolic syndrome, type 2 diabetes, and cardiovascular disease // Diabetes. 2007. Vol. 56. P. 2655-2667.

(C) Николаев B.T., 2021 